\title{
Corynebacterium diphtheriae bv. belfanti
}

National Cancer Institute

\section{Source}

National Cancer Institute. Corynebacterium diphtheriae bv. belfanti. NCI Thesaurus. Code C122273.

A biovar of Corynebacterium diphtheriae disting uished by its morphogenic and biochemical properties. Biovar belfanti is positive for fermentation of glucose and maltose. This biovar is one of the two main disease-causing biovars. 